Прегледни рад

Adam A. Rixer

Károli Gáspár University of the Reformed Church in Hungary

Faculty of Law

rixer.adam@kre.hu

\title{
ADMINISTRATIVE JURISPRUDENCE AS A POPULAR SCIENCE IN HUNGARY
}

Abstract: Why should administrative jurisprudence not also be one of the popular sciences? Why only physicists have the privilege to talk about their own field in a way that is accessible, understandable and interesting for many?

After defining the general concept of science promotion, this study briefly presents the main goals of promotion, including the skills that can be developed the most through these promotion efforts, the administrative areas that, in our opinion, are of the most public interest, new communication opportunities and channels and concrete (methodological) solutions that increase opportunities for addressing and dialogue, including the interdisciplinary fields that use and present results of administrative law. It proceeds to consider answers regarding the matters of what skills and knowledge the ideal promoter should have and what social target groups can potentially be the focus of promotion efforts. The study also captures the general and administrative knowledge limitations of science promotion before concluding with a summary of the results obtained.

Keywords: administrative sciences, jurisprudence, popularisation, science promotion, Hungary

\section{INTRODUCTION}

Administrative law, both as a separate branch of law (body of rules and procedures) and as jurisprudence (i.e. as a group of phenomena generating knowledge and a scientific community), faces significant challenges. One of the reasons behind this, which may also be relevant to our topic, is the increasing importance of market-based and outbound knowledge management in all educational institutions. Another is, of course, the increasing importance of knowledge sharing, which can be closely related to the transformation of the structure and character- 
istics of the channels that transmit it. An increasingly important aspect of this transformation is the promotion of science and a new field for the dissemination of scientific results. Through the dissemination of the results of the individual scientific workshops, their transfer to old and new staff and the strengthening of the image of a wider institution, increasing the indirect and direct revenues - as a goal - becomes more and more important on the lists of various institutional priorities and plans, even at international levels.

Today, the presentation of the results of the administrative sciences (including administrative jurisprudence) in the world outside science is not only some kind of theoretical possibility - the 'desire of appearance', if you like - but an unavoidable need. Extensive science, which can only be found in education as an up-to-date discipline, can have a real impact on its subject matter. The inevitability of repositioning this science follows from the increasing speed of legal changes, the achievements of some new frontier sciences, the changes in the level of knowledge and needs of recipients and the radically new channels of knowledge transmission. However, all these aspects radically transform not only the curriculum and teaching methodology of higher education but also the characteristics of multifunctional 'dissemination', which constantly involves 'clients', supporters and 'potential stakeholders' as a result of the marketing efforts of third-generation universities.

Approaching our topic differently: why should the science of public administration (or even administrative jurisprudence alone) not also be one of the popular sciences? Why only physicists have the privilege to talk about their own field in a way that is accessible, understandable and interesting for many?

After defining the general concept of science promotion (Chapter 1), this study briefly presents the main goals of promotion, including the skills that can be developed the most through these promotion efforts (Chapter 2), the subjects (administrative areas, issues) that, in our opinion, are of the most public interest (Chapter 3), new communication opportunities and channels and concrete (methodological) solutions that increase opportunities for addressing and dialogue, including the interdisciplinary disciplines that use and present results of administrative law as a field of law and branch of jurisprudence (Chapter 4). It proceeds to consider answers regarding the matters of what skills and knowledge the ideal promoter should have (Chapter 5) and what social target groups can potentially be the focus of promotion efforts (Chapter 6). The study also captures the general and administrative knowledge limitations of science promotion (Chapter 7) before concluding with a summary of the results obtained.

In addition to the theoretical approaches, the study also provides concrete examples of new solutions used in the digital space, these being application-based developments through which a wide range of useful information becomes available to young and old people alike. It is worth noting here that one of the advantageous features of administrative law in terms of the possibility of popularisation 
is that everyone gets in contact with it voluntarily or even involuntarily. Moreover, there is a constant hunger for information, and the satisfaction of this may be partially the task of the promotion of creative science.

\section{THE GENERAL CONCEPT OF SCIENCE PROMOTION (POPULARISATION)}

Views are very mixed in regard to the genre of popularisation within the ranks of science. It is not always clear what might be considered promotion, but opinions are strongly divided regarding the terms of the value of promotion. In connection with the concept of philosophical promotion, László Nemes noted that the concept essentially perceives that an author who is well-informed and possesses good writing skills may communicate current developments in academic science to the wider public in a more simple and understandable way.

This approach allows at least two conclusions to be drawn. First, the promoter typically does not articulate their own original insights; instead, they primarily present the perceptions of others in a summative way. Second, the target audience of the popularising author is primarily not the community of professional philosophers, but a wider range of educated and curious people. ${ }^{1}$ Nemes also noted 'that despite of a scientist or philosopher writes [only] topics, which are interesting to many, or are understood by many, and thus becomes popular (in his life or after his death), obviously cannot be equal with being popular. Friedrich Nietzsche, Jean-Paul Sartre, Peter Singer or, say, Slavoj Žižek are popular authors, but that does not mean, that they are simply conveying the views of others towards a wider readership'. ${ }^{2}$

Further studies on the roots of the concept and its current meaning have shown that we may also identify a recurring conceptual element in the relevant literature popularisation of science, which also means programmes 'supplementing and supporting school education'. In this way, it is always closely related to public and higher education and inseparable from them. Moreover, they are connected in several ways, as we will see later. ${ }^{3}$

There has been some legalisation of the concept, such as through the emergence of the right to benefit from the results of science. Article 27 of the Universal Declaration of Human Rights of $10^{\text {th }}$ December 1948 summarised this right in the following statement, which the international community considered noting

\footnotetext{
${ }^{1}$ László Nemes, „Filozófiatörténet kezdőknek”, Kultúra \& Kritika: A PPKE BTK Esztétika Tanszékének kritikai portálja, 12 July 2016, http://kuk.btk.ppke.hu/hu, 13 January 2019.

${ }^{2}$ Ibid.

3 Éva Gajzágó, „Tudománynépszerüsítés süvöltő lángcsóvával”, Élet és Tudomány, 3/2015, 1371 .
} 
important at that time: 'Everyone has the right freely to participate in the cultural life of the community, to enjoy the arts and to benefit from scientific achievements and its results'. ${ }^{4}$

Even in the absence of an exact concept of science promotion, it is clear that it is an activity that consciously organises contemporary results and presents them in a cohesive way, one which can be closely related to some of the educational activities organised or authorised by the state, either through the promoter or the recipients. This definition is sufficient for us to move on to the individual sub-questions, through which we will clarify and shape our 'concept of work'.

\section{WHAT ARE THE MAIN GOALS OF THE PROMOTION ACTIVITY IN GENERAL AND IN RELATION TO STUDIES REGARDING ADMINISTRATION AND ADMINISTRATIVE LAW?}

First of all, it is worth asking ourselves what we expect from promotion. What could be the decisive merits of this activity that justify its application and development? For the sake of simplicity, we shall first separately examine the primary and direct goals and the following indirect goals that can be achieved through the former.

The most obvious direct goal should be to transfer the material knowledge to those who are interested in it. This includes the updating and systematisation of the existing knowledge. ${ }^{5}$

To put it simply, the promotion of science in general and in our own narrower field has an informative function (which has an essential social purpose). This is ideally complemented by an entertaining function. The existence of the entertainment function suggests that participation on the part of the recipients is not obligatory or compulsory in the way school may be; on the contrary, their presence is driven by volunteering and a desire to gain knowledge.

Indirect goals can be realised through the former, as an independent effect, by showing that in addition above the mere participation and the received information, the individual's personality show changes and positive developments in their attitudes and skills. It is worth thinking about specific areas of skill development. The strengthening of democratic skills and the need for developing empathy are also of paramount importance in our narrower field.

${ }^{4}$ For an expose of this aspect, see László Z. Karvalics, „A tudományművelés és a tudományokban való jártasság, mint emberi jog. Egy arkhimédészi pont azonosítása", Acta Humana, 3/2019, 119-135.

${ }^{5}$ The importance of this promotion increases especially in periods when the legal acts created by the administration and its interpretation needs (tasks) can be connected to situations of emergency (see, for example, the case of the COVID-19 epidemic). 
An additional goal may appear (in a hidden way) as a specific goal definition, which assumes that the effect may also contain reciprocal moments. The promotion of science can become a field for feedback markers related to policy, legislation and law enforcement, particularly in connection with topics that realise the importance of the flow of information related to the functioning, practices and self-image of the state.

Among the development and strengthening of democratic skills, it is important that it is not enough to be described the institution of legal remedy in classroom conditions (and we cannot be even less satisfied with it in situations outside the school system): the institutions of democratic participation, equal involvement and presence (being involved) must be constantly represented in practical forms. Democratic thinking that is independent of external circumstances cannot be developed simply by providing information in this regard. Ensuring the personal livelihood of participatory institutions in the dissemination process is one of the main duties of administrative law educators and 'promoters'. Concrete solutions can take many forms. Various types of teamwork, the release of alternative tasks, the development of opponent-type roles, the application of the majority principle in some respects, situational exercises and simulations can all be tools for 'involvement', participation and cooperation (see Chapter 4 for details).

Of course, different applications can play a similar role. We should also note that the surfaces, solutions and so on that seem to be new today inevitably become commonplace after a long time, which also means that one of the measures of the popularity of science is precisely the extent of becoming known, settling in and 'integrating'.

As indicated above, another direct goal of disseminating the knowledge of administrative law is to develop empathy in response to one of the most significant new needs of our time. Directly 'visiting' real issues and meeting with characters through role-plays and simulations can be suitable for developing empathy; if the educator or science promoter prepares them appropriately and devotes sufficient time to achieving these goals. Similarly, the use of non-legal social science (i.e. psychological, sociological, economic and other specialist) literature and expertise on a described real or fictional case may increase the complexity of the case management. By broadening this approach, it will be possible to develop essential general and professional competencies. For example, in a child protection situation or in cases of domestic violence, it is typically necessary to understand and use non-legal professional resources, empathy and emotional processing skills. Moreover, there is also a need for the student or the recipient of the promotional communication to be critical with unexpected, dysfunctional consequences of the legal operations and interventions. How can non-legal information be translated for legal procedures? How can it be made acceptable to the court? In systems of legal traditions, where there is no prior openness to accepting such issues, these 
issues usually do not arise, although the strategic use of the social sciences and the ability to process this expertise can be useful in legal procedures. ${ }^{6}$ Regarding science promotion in legal education, Fleck stated that "making the basic structure of legal activity, the personal consequences and requirements perceptible can only be achieved by involvement, direct experience and sensitization. The perception of injustice, the personal commitment to opposition and criticism, develops only by formulating one's own role. The definite task of training is to bring back the understanding of human suffering into the special professional aspects, to encourage personal involvement. This is mostly possible by directly perceiving the deep texture of personal narratives, characters with names and faces, relationships and events. Law students learn typical legal thinking very early on, this recall (sensitization) can cause confusion that needs to be addressed, so pedagogical sense, even more pedagogical competencies are expected from educators'?

Understanding human suffering includes consideration of the fact that the person working in public administration does not simply perform law enforcement and services and organises activities; they also encounter and can become partly involved in human conflicts, 'destinies' and emotionally and morally challenging situations.

Is it possible at all to resolve a dispute or settle any more serious 'legal' issue in such a way that we completely exclude emotional difficulties and mental injuries and their consequences from the process? Our answer is a definitive no, and we can even reasonably assume that the dissemination of knowledge related to public administration and administrative law should specifically aim to develop the ability to empathise and also generate propensity for altruism.

Of course, we do not question the fact that the main strength of the legal system is given by the fact that it is able to reach more or less objective decisions by keeping an equal distance from the parties, being impartial and excluding feelings and desires. Nonetheless, to increase the capacity for compassion would enable us to perceive parallel realities, complexity and certain universes that go further from the law.

In the above, we have indicated the impact of science promotion efforts among the indirect goals of science and the post-scientific legal life, as well as the realisation of the 'reciprocity' dynamics. The promotion of public administration science and its transmission to the non-scientific spheres of the public-similarly to the school-based education of public administration law - can itself stimulate the whole field, forcing continuous summarisation, systematisation of accumulating knowledge, further research on possible forms of knowledge transfer and so on. Ideally, the science promotion activity may also have a retroactive effect

\footnotetext{
${ }^{6}$ Zoltán Fleck, „A jogászképzés módszertani dilemmái”, Neveléstudomány, 4/2018, 35.

${ }^{7}$ Ibid.
} 
on science. This raises the question: can the feedback and needs of the lay consumers of science be incorporated into science and therefore, directly or indirectly, into legislation and law enforcement?

The possibility of such an effect is also supported by the current direction of the development of science. The time of successive and reactive science has expired, and the time of exhausted science based on describing existing solutions is coming to an end. We must also take into account the fact that the intensity of change also increases the compulsion of all 'available' social actors (partners).to cooperate and 'think together'.

We must also consider that there is a significant personal overlap between the representatives of science and the professional actors of administrative legislation and law enforcement. This dual role can naturally also branch into science promotion. The organised promotion of the results of public administration sciences is also a very complex system of relations between the staff of public administration, the representatives of science and the recipients. At best, it is not a oneway communication, but a continuous and reciprocal mechanism of action. Both the international and domestic specialist literature indicate that all this is no longer just a theoretical possibility. The so-called phenomenon of civic science has also appeared $^{8}$ to ensure the high-efficiency use of voluntary scientific work in government activities and, ultimately, to socialise science policy, ${ }^{9}$ one of the direct aims and consequences of which is to increase the general receptivity towards science. ${ }^{10}$

\section{POSSIBLE OBJECTS OF SCIENCE PROMOTION}

Administrative law and the broadest science of public administration have thus far not been included in the final list of 'popular sciences', despite it being a fact that public administration and administrative law are inevitably and massively present in the daily lives of all citizens. This can lead to the special situation where the various transaction descriptions, prospectuses and summaries prepared for the clients have a science-promoting nature due to the highlighting of relevant issues, the simplification approach and the intention of the process-like representation. This is useful if they are related to the science of communication, social psychology, etc. and reflect some of the achievements of administrative jurisprudence (mainly related to the content of the communication).

\footnotetext{
${ }^{8}$ László Z. Karvalics, „Állampolgári tudomány és önkéntes erőforrásszerzés mint paradigmatikus, szakpolitikai és menedzsment-kihívás”, Új Magyar Közigazgatás, 1/2019, 44-53.

${ }^{9}$ Ibid., 49.

${ }^{10}$ Ibid., 51-52.
} 
It is worth noting that scientific results appear here as consumer goods for people whose professional knowledge on most of the emerging issues is imprecise or limited to the extent required in their everyday lives. Moreover, it is precisely in the areas of legal relevance that most of the existing knowledge is false and based on prejudices, rumours and misinformation. ${ }^{11}$ Science promotion is often not simply about offering and incorporating new knowledge; it is also about weeding out misinformation and replacing it with factual, accurate knowledge.

Now, the question posed in the title of the chapter must be answered: what topics can be presented in Hungary today that would be of scientific value and public interest and clearly presented for this purpose?

This is definitely like a public law preparation of a Roma-Hungarian compromise - without claiming completeness - through the publication of the reasons and results, presentation of the arguments in favour of the establishment of an independent Balaton county, an outline of the possible administrative aspects of Székely cultural autonomy, presentation of new legal/administrative contexts related to migration, 'sorting out' the content of comprehensive and mandatory migration-related training for those working in the public service sector, the potential public and specifically administrative legal elements of the missing regulations for e-sports, familiarisation with the meaning and significance of expulsions in the social fields, acquaintance with its legal and other contexts, the expected impact of climate change on Hungarian settlements (including presenting the effects resulting in the changes in settlement structure) and so on.

Based on only a few hand-picked topics, it is clear that very popular, meaningful and forward-looking scientific promotion efforts can be found in Hungary that correspond to the goals described in the previous chapter and demonstrate dominant legal/administrative relations.

Of course, knowing the age composition of most promotional occasions, it is safe to recommend - even on a roadshow basis - a comprehensive presentation of settlements in a special situation regarding several administrative issues (Sopron, Budapest, Debrecen, etc.). Significant added value could be produced through projections, historical overviews and the presenting of contemporary challenges. The systematic aligning of facts has a strong effect from the outset, and in addition to the legal sciences, it can also be possible to transmit political science, sociology, social psychology and other fields of knowledge in a creative way.

One of the recurring and always interesting areas of administrative law is the renewal of the language of administrative law. Participants can be actively involved in 'inventing' the Hungarian equivalent of words that exist only in phonetic transcription or in a completely foreign language. Calls for entry regarding

${ }^{11}$ See, for example, Bernard-Henri Lévy, „Google, fake news és az igazság válsága”, Heti Világgazdaság, 8/2019, 65. 
related applications may also be a good example of the meaningful involvement of the 'recipients'.

\section{FORMS, METHODS, SOLUTIONS, ETC. THROUGH WHICH SCIENCE CAN BE CONVEYED TO AUDIENCES OUTSIDE THE WORLD OF SCIENCE}

\subsection{General questions}

Administrative law, as a branch of law and an educational discipline, is about to be renewed. In fact, it can be said to be experiencing a renewal at this present moment, not only in terms of content and dogmatics but also specifically in the field of methodology and didactics, and brings us back to the promotion of science.

As a starting point, let us note that effective and credible promotion of science has two elementary preconditions: the correctness of the content of the information conveyed and its comprehensibility. These can be referred to as 'methodological requirements'. Angéla Gábri drew attention to the requirement of clarity related to another field of law (decisions made according to the Code of Criminal Procedures), stating the 'three main requirements of a comprehensible phrase are that the audience: a) can find what they seek, b) understand what they found and (c) are able to use the information to meet their own needs'. ${ }^{2}$ This is similar to the words of Róza Vajda, who interpreted the concept of actionist science and held that one of the keys to the democratisation of access to science as a resource is comprehensibility. ${ }^{13}$

On the issue of content, we are convinced that administrative jurisprudence can have results that are worth knowing and can be shared with the wider social public (see the topics marked in the previous chapter); we just simply need to find the right forms. Obviously, this should not involve someone presenting excerptions from the classics of Hungarian public administration science during the commercials for current reality TV shows and weather reports. Moreover, the goal is not to become tabloid by proposing politically frequented and topical issues. Nonetheless, there is a need for channels if we want to promote useful, inclusive knowledge and results.

Traditionally, the most basic form of knowledge transfer and the starting point for popularising science - at least in social science topics - has always been the transfer of information based on the recipient's own prior knowledge (e.g. visible communication based on the facts of 'I've seen it', 'I've heard it' or 'it is

${ }^{12}$ Angéla Gábri, „Közérthetőség a hazai büntetőeljárási jogban”, Jogtudományi Közlöny, 12/2019, 503.

${ }^{13}$ Róza Vajda, „Mi fán terem az akcionista tudomány?”, Szociológiai Szemle, 1/2019, 149. 
useful or interesting'), which is clean, easily accessible and as simplified as necessary. This can be considered a type of communication that offers ready-made, easy-to-interpret solutions and possibly provides new models that unite seemingly disparate phenomena with a plausible explanation for their relationship that is 'able to answer all our questions' and presumably even provides benchmarks for later phenomena. To a certain extent - following the footsteps of Aristotle - the popularisation of science is a reflection of reality in artistic forms (a mimesis), which also implies that on the receiving side - among other things - we can find a kind of enjoyment of art and a better way of understanding a previously known phenomena.

\subsection{Methods}

Of our four basic methods of promoting science, the first is the lecture form. This is performed in front of an audience and typically involves the use of a technical aid. The second is the written form, which - in the case of administrative law - necessarily means an understanding-oriented, limited use of legal specialist language. The third - practical involvement - involves the implementation of simulations, related explanations and scientific information, while the fourth is based on non-personal presence (typically being present through digital platforms). Of course, it is also possible to utilise a mixture of these.

Whichever 'basic method' we use, we need to be aware that some scientific genres serve the cause of promotion more than others. Károly Tóth noted decades ago that 'A monograph [...], no matter how small, is inherently difficult to reconcile with popularization, it can hardly serve the purpose of popularization. I would say, that a book of science does not describe the results of a particular field (so it does not list facts); but moves the imagination. It no longer builds on pre-existing interest; but seeks to awaken it. It stimulates not the stomach, but the appetite. Its formal characteristic, lightness (Endre Barabás's criterion) is not a determinant of the genre, but only a carrier of the mentioned content feature'. ${ }^{14}$ Understanding Tóth's statement and considering it sustainable, it should be noted that a monograph (particularly small monograph) can also be suitably professional while also being a readable, enjoyable communication of scientific facts (the latest example of this work in the field of administrative law is by Szilvia Köbel ${ }^{15}$ ). Whatever the truth is about the possibilities of monographic works, we must also take into account that just as literary teaching cannot be permanently pushed back to hundred-yearold structures, the results of the digital shift cannot be excluded from methodological solutions.

\footnotetext{
${ }^{14}$ Károly Tóth, „Tudomány-népszerüsítés vagy ismeretközlés?”, Korunk, 1/1974, 142.

${ }^{15}$ Szilvia Köbel, Az emberi jogok védelmezöiböl a „nép ellenségei”. A Magyar Közigazgatási Bíróság megszüntetése 1949-ben. Patrocinium, Budapest 2019.
} 
Independently from the basic method and the chosen 'genre', it can be stated that according to the requirements of today, there is a general and scientifically based and developed methodology that also includes the transfer of information and is unavoidable for most science promotion experiments: the so-called experiential education. One of the possible general answers to our question about how to deliver knowledge is, therefore, experiential pedagogy. ${ }^{16}$

According to Kurt Hahn (the founder of experiential pedagogy), the goal of school education lies in personality development. The formation and survival of diligence and the development of perpetuating curiosity and compassion are perhaps the most important elements. ${ }^{17}$ One of the defining directions of a school is the training model, which operates according to so-called experiential learning. The essence of it is the development of personality and maturity through the process of active experience, rather than the acquisition of academic knowledge. ${ }^{18}$ Its components are most often external locations and unexpected but lifelike tasks that, in addition to developing individual competencies, also contribute significantly to participants getting to know others better and increasing the effectiveness of teamwork. The individual task elements are always built on top of each other and usually end with an evaluation. Evaluation helps participants to reflect on fresh experiences and become aware of new experiences, including new professional experiences. Tasks are usually designed to be challenging for both the individual and the team while still being achievable by everyone. ${ }^{19}$

The above should also be taught in the field of public administration in relation to the dissemination of knowledge of administrative law, out of the context of the usual classroom environment, through excursions to institutions, on-site simulations and other similar frameworks. These forms naturally bring educational experience through lifelike and complex cases and phenomena, with the additional advantage of achieving the goals that students may already have.

Experiential pedagogy is thus closely related to the complex problem-solving skills mentioned earlier insofar as these 'legal cases' allow connection, involvement and active learning, regardless of the level of prior knowledge. Such topics can be, for example, the extreme challenges and effects that the administration of Sopron is facing today or the administrative relations and elements of a GypsyHungarian public law settlement. Ultimately, experiential pedagogy results in the practice of frontal knowledge transfer in the form of a simulated board meeting or contravention hearing, possibly as part of higher education or an out-of-school administrative and literature course.

${ }^{16}$ Beáta Csimáné Pozsegovics, Edina Sáriné Csajka, „Élménypedagógia a minőségi időskorért", Képzés és Gyakorlat, 4/2017, 69.

17 Ibid.

${ }^{18}$ Ibid.

${ }^{19}$ Ibid. 


\subsection{More important new (inter)disciplines for the promotion of science related to administrative jurisprudence ${ }^{20}$}

As already seen in the previous subsection, the methodological renewal can be traced to before the explosive change of information technology. A further stimulator of this renewal is the emergence of novel (partial) sciences and frontier disciplines in contact with administrative law, insofar as the basis of their independence is often the specific way of generating and delivering knowledge.

Among the administrative sciences (sub-disciplines of public administration), there are traditionally some 'major' sub-disciplines, such as administrative law, political science and administrative organisation science. Statistics, sociology and even economics have also long been decisive in the study of public administration. Of course, the list can be continued at length (mostly by mentioning interdisciplinary disciplines), and the longer the list, the most important question for our present topic arises in a more tense way: is there a substantive relationship between administrative law and other sub-disciplines, and how are they able to interact and produce useful - or at least interesting - additional knowledge for lay people about the legal aspects of public administration?

So, what are the disciplinary areas that can best support, complement and reinterpret the results of traditional legal approaches to public administration in line with the legal and social changes described earlier? ${ }^{21}$

The following list intends to systemise the most significant parts of these areas in the present without considering the detailed presentation or the sub-issues that are decisive for the promotion efforts within the present framework.

Archontology. At the heart of this historical auxiliary science is the retrospective catalogue of practitioners of each profession and the study of individual careers. In the case of our narrower subject, drawing up the profile of the administrative judges may be the most exciting attempt; through this, the fate of an individual destiny and the legal life of an era can be perceived.

E-government. Since the 1990s, informatics has penetrated the sciences also on the material level. The concepts, methods, digital equipment and computer technology are all integrated into the fabric of the cultivation of the given field of science - in our case, administrative sciences and administrative law - and create new professional 'qualities'. ${ }^{22}$ Global trends, developments within the European

${ }^{20}$ This subchapter was prepared using the book of Ádám Rixer. Ádám Rixer, A magyar közigazgatási jogtudomány értékelésének szempontjai [Aspects of the Evaluation of Hungarian Administrative Jurisprudence], Ludovika, Budapest 2020.

${ }^{21}$ Fleck puts it this way: 'The transformation of law implies the need for multidisciplinarity in education'. Z. Fleck, 31.

${ }^{22}$ Zsolt Czékmann, Lilla Nóra Kiss, „The Concept of E-administration in the Hungarian Regulation”, Juridical Current, 1/2015, 73-88. 
Union $^{23}$ and very local developments are of growing importance and interest to many people in e-science research, resulting from the new information and communication technologies. ${ }^{24}$

Philosophy. The changes of our time are also forcing the re-creation of some kind of philosophical synthesis between the legal norms governing public administration and the facts of real operation. In recent decades, Hungarian legal and jurisprudential thinking has not shifted towards philosophical reflection; 'Satisfied with the answers required by practice, [...] giving up on finding great and final answers. ${ }^{25}$ However, the change has begun; the attention of administrative jurisprudence, among other things, is increasingly turning towards the question of how to increase the penetration of moral principles into the world of law. ${ }^{26}$

Why is this need coming to the fore now? Society, as well as the content of law, is changing rapidly. Inseparably from them, the internal structure of jurisprudence is also changing and gaining new focus points. It is worth clarifying, as a kind of proposition, that administrative jurisprudence itself cannot be analysed in a mere dogmatic manner. According to Jakab and Menyhárd, 'Although traditionally the heart of legal framework is a conceptual clarification (legal dogmatic) analysis of the law in force, legal science does not only conduct legal dogmatic research. [...] We also consider legal history [...] as well as jurisprudence, as well as de lege ferenda, empirical, and political philosophical questions of law as jurisprudence'. ${ }^{27}$ This statement is valid when applied to administrative jurisprudence and is also relevant to the present research in the context of the promotion of administrative law. The shift in jurisprudence in the discussion that has just been outlined certainly reinforces ethical, moral and (ultimately) philosophical issues, as well as the demands of society as a whole to discuss them together. All this introduces a new element of administrative jurisprudence (as what may be considered a new field) as well as popularisation as an independent factor in the professional discourse.

${ }^{23}$ Gyula Csáki-Hatalovics, „Új trendek Európában az elektronikus közigazgatás területén”, Glossa Iuridica, 3-4/2017, 71.

${ }^{24}$ Róbert Lendvai, „Elektronikus közigazgatás kistelepülési szinten”, Comitatus, 4/2017, $52-58$

${ }^{25}$ Miklós Szabó, ,Szó szerint... A jog és nyelv interferenciájáról”, Jog és nyelv (eds. Miklós Szabó, Csaba Varga), PPKE, Budapest 2000, 2.

${ }^{26}$ In recent Hungarian literature, Bordás, for example, refers to the renewed relationship between philosophy and administrative jurisprudence (our narrower topic) when he states that the new concept of integrity is directly due to the 'new [philosophical' approach of the state, including ethics. Mária Bordás, „Gondolatok a közigazgatás-tudományról”, Polgári Szemle, 3-6/2012, 14.

27 András Jakab, Attila Menyhárd, „A magyar jogtudomány helyzete és kilátásai”, A jog tudománya: Tudománytörténeti és tudományelméleti irások, gyakorlati tanácsokkal (eds. András Jakab, Attila Menyhárd), HVG-ORAC, Budapest 2015, 25-26. 
Hungarology. With the expansion of the concept of public administration and the emergence of autonomy debates and substantive administrative tasks related to Hungarians living abroad, public policy aimed at building the state and public administration consciously promoting Hungarian culture, new frontier sciences and interdisciplines also play a meaningful role in the study of public administration and administrative law as well as in the transmission of demonstrable results. ${ }^{28}$ Incidentally, among the aspirations of this science, the moment of knowledge transfer and dissemination abroad is also a particularly important element. ${ }^{29}$

Identity sciences. The so-called emergence of changes in the role perception and self-image of the state outlines the contours of identity science. Almost one moment from the other, this question came into prominence almost instantaneously in the 2010s: what political, legal and other identity (self-identity) does Hungarian policy have in the lives of the public and science?

The concept of identity science was previously interpreted in a restrictive way as ethnography and similar sciences that describe and systematise traditions. Both legal and constitutional identity have now come to the fore in relation to the various actors and entities playing a role in public administration and in the life of the state as a whole and in certain elements. European integration has both transformed and strengthened the need for the self-identity of individuals and communities (nations). ${ }^{30}$ In parallel with globalisation, this is why the identity debate has become one of the most interesting scientific phenomena.

Communication science and public administration communication science. The study of internal and external communications of public administration does not only seek to explore actual and ideal communication strategies and concrete solutions; it is also increasingly important for science to describe public administration itself, considering its role and specific actors. ${ }^{31}$

${ }^{28}$ At the same time, this means that the growing interest in the field increases the intensity of scientific and other debates. See, for example: Nándor Bárdi, „Álságos állítások a magyar etnopolitikában. A külhoni magyarok és a budapesti kormányzatok magyarságpolitikája”, Hegymenet. Társadalmi és politikai kihivások Magyarországon (eds. András Jakab, László Urbán), Osiris, Budapest 2017, 130-155.

${ }^{29}$ Margit Kissné Pap, „Áttekintés a hungarológia jelenlegi helyzetéről és a fontosabb további feladatokról", Hungarológia, 1-2/2000, 25.

${ }^{30}$ For more details, see Tibor Navracsics, „Nemzeti érdek és Európa”, Pro Publico BonoMagyar Közigazgatás, 4/2014, 100-104.

${ }^{31}$ Jarrett J. Gregory et al., „Communications”, Public Administration Review, 6/1984, 551557. There is a dual relationship between public administration and the media: on one hand, the media shapes the image of public administration in society, and on the other hand, public administration regulates and supervises the media, through which (usually indirectly) society's perception of public administration can be shaped. For more details, see: András Bencsik, Adrián Fábián, 
Public administration and literature. In Hungary, 'law and fiction' has become a stable discipline that seeks to explore the fictional connections between legal phenomena. The most characteristic approach of the research area examines how law appears in literary works (law in literature). ${ }^{32}$ If we analyse the significance and possibilities of the various 'Law and Fiction' courses gaining popularity across the world from a purely educational and methodological point of view, we may see that legal-type problems do not reach students through real cases, but rather, through stories that are somehow related to reality but dressed in a literary cloak. The presentation and interpretation of individual legal institutions on the basis of a 'common experience' can only provide traditional studies to a limited extent, as the majority of students - particularly in Prussian-type educational environments - have no substantial professional knowledge and might participate in their courses in an 'unprepared' or limited way. This method leaves an unnecessarily large space for the instructor, who - at least in Hungary - often only repeats and 'reproduces' the lectures on seminar-type occasions.

Following the example of the 'Law and Fiction' approaches - narrowing them down to one area - the possibility ${ }^{33}$ of Hungarian literature-based courses related to 'Public Administration and Fiction' that incorporate dimensions beyond the law has also emerged, not only in higher education, but also outside it.

Linguistics. Mother tongue is the most important determinant of community culture. In Hungary, the sociopolitical dimension of language seems to be strengthening recently, with fear of external influences against identity also coming to the fore. ${ }^{34}$ In the case of small languages, a particularly important element (tool) of forming and maintaining scientific communities is language - the existence and continuous care of independent terminology. The current state of the legal/administrative language and its challenges and innovative experiments are all areas worthy of public interest. The introduction of Euro-language influences, Anglicisms, new word distortions and other exciting phenomena as well as other attempts to preserve and develop language in connection with public administration (for example, the employment of language guards in ministries) can easily be made interesting issues for all ages. An attempt for language renewal can itself have a science-promoting effect.

Psychology. Psychological analyses affecting public administration can be perceived mainly in the context of the wider public administration (typically in

\footnotetext{
Emese Pál, László Gergely Szőke, „A közigazgatás és a média kapcsolódási pontjai”, Pro Publico Bono - Magyar Közigazgatás, 4/2015, 60-75.

${ }^{32}$ István H. Szilágyi, ,Jog és irodalom”, Iustum Aequum Salutare, 1/2010, 5.

${ }^{33}$ As the founding work of the field, see: Ádám Rixer, „Közigazgatás és szépirodalom”, Pro Publico Bono - Magyar Közigazgatás, 3/2015, 49-72.

${ }^{34}$ György Schöpflin, Az identitás dilemmái. Kultúra, állam, globalizáció, Attraktor, Máriabesnyő-Gödöllő 2004, 143.
} 
connection with the performance of tasks performed by civil servants ${ }^{35}$ ) or in general, in the broader public policy sphere, ${ }^{36}$ or in sphere-independent topics. ${ }^{37}$

\section{WHAT DOES AN IDEAL PROMOTER LOOK LIKE?}

The ideal promoter is simultaneously a practitioner who can provide up-todate examples on almost any issue that arises and a scientist with a theoretical interest who is able to produce new syntheses with their ability to systematise and generalise.

This promoter is an excellent performer who is well-informed regarding the new possibilities of information technology while also keeping their attention on what they have to say, mixing interesting elements of content with a bit of humour. The significance of the latter cannot be overestimated. The specialist literature also identifies it as having a prominent role in relation to the promotion of other sciences: Discussing Warburton, Nemes held that he was 'the grand master of science promotion. He does not only cleverly select the essential problems, but is able to present the great questions of philosophy with excellent writing talent, with using seriousness, irony and humour all together. This is the most obvious method that knocks down the most walls: communication of facts embedded in humour'. ${ }^{38}$ If we look for a good example from the broader range of administrative sciences, the eternal work of Parkinson shall be evoked in our minds. ${ }^{39}$ The easy transition between official quality and private communications, between examples from practice and the contemporary literature, is also part of the complexity provided by the promoter. Reconciling multiple qualities is a significant challenge in most cases..$^{40}$ In the modern Hungarian legal and administrative higher education, we see that pedagogical awareness and methodological preparedness are not aspects considered in the selection of lecturers or the evaluation of teaching work. From the point of view of our topic, this is also important. The basic precondition of any kind of popularisation of science is a high, significantly above-average

${ }^{35}$ Burnout is a common syndrome of staffs providing auxiliary occupation. András Gábor Szényei et al., „A kiégési szindróma megelőzése - a hagyományoktól a modern információs technológiákig", Magyar Pszichológiai Szemle, 4/2015, 847.

36 Tamás Bereczkei, „A manipuláció müvészete. A machiavellizmus kognitív és evolúciós alapjai”, Magyar Pszichológiai Szemle, 2015, 70 (1), 7-22.

${ }^{37}$ See, for example: Mária Fekete, András Grád Pszichológia és pszichopatológia jogászoknak, HVG-ORAC, Budapest 2012.

${ }^{38}$ L. Nemes, 2.

${ }^{39}$ C. Northcote Parkinson, Parkinson törvénye vagy az Érvényesülés Iskolája, Minerva, Budapest 1990.

${ }^{40}$ Gábor Füzér, „A konzultáns, az előadó és a kapcsolatteremtő”, Üzlet és Pszichológia, 3/2013, 30-32. 
awareness in reaching out to people outside the closed world of science and providing them with digestible information. This awareness and the consequent effective knowledge transfer can most likely be provided by those who have experience and skill-level answers in relation to pedagogical, methodological and tool-use issues.

\section{WHO CAN BE CONSIDERED THE MAIN TARGET GROUP?}

While it is pertinent to suggest that some form of abstract prior knowledge and/or personal experience is required to acquire knowledge of administrative law, this does not necessarily contradict the view that the learning process driven by arousing interest in public administration sciences cannot be started early; there is no need for a continuous client-citizen relationship with the authorities or some kind of 'graduation level'. It is worth stating as a hypothesis that the transmission of administrative and administrative legal knowledge in the framework of science promotion is possible for practically all age and social groups; moreover, it is even highly desirable. From primary school age onwards, the use of this form has been already justified in the context of the 'qualification for active citizenship', and in the case of groups living with social disadvantages for some reason (women, children, Roma, the elderly, the disabled, etc.), solutions for knowledge transfer outside traditional channels and creative ways to provide information are badly needed. Thus, compiling an exhaustive list of groups to be involved, or even the layers that are most 'targeted' in the present case, is not necessarily justified.

\section{GENERAL AND ADMINISTRATIVE LIMITATIONS OF KNOWLEDGE-RELATED SCIENCE PROMOTION}

Third-generation universities, in contrast to first- and second-generation universities, actively seek to exploit, utilise and place the knowledge created on a business foundation, creating for itself a new, third goal, with importance equal to that of the previous two (scientific research and education). ${ }^{41}$ On the basis of this changed role perception and self-image, investors and other similar sponsors who hope to make profit in the long term can be involved. In addition, this might also be the most exciting area for science promotion. Investors and sponsors are becoming increasingly involved in a competition, with higher education and other research entities competing with each other to obtain orders, research assignments

${ }^{41}$ Szilvia Deés, Egyetemi tudománymarketing. A harmadik generációs egyetem szemlélete és kommunikációja. Phd thesis, PTE DI, Pécs 2011, 35-36. 
and other forms of financial support in an expanding, strengthening and highly competitive market. Science promotion efforts, until now, promised only indirect benefits, being intended to increase or raise the awareness and reputation of the institution or the lecturer. However, we can assume that the market aspects are becoming more and more important in this primer area as well, in parallel with the growing importance of the area. We need to take into account 'the specific nature of post-academic sciences: the pursuit of a more intensive use of knowledge and entrepreneurial behaviour in science ${ }^{42}$ and the fact that 'society increasingly expects scientific institutions to solve practical problems, but at least provide results in science, which can be used in some form, at least indirectly, in the foreseeable future. For example, to contribute prosperity and economic competitiveness, or helping to solve social, economic, healthcare, technical, cultural, etc. problems' ${ }^{43}$ Obviously, in the context of the technical sciences, the symbiosis of the market and science makes more sense; in comparison, the administrative sciences - with the exception of a few sub-fields, often with technical implications - always lag behind. It is also more difficult to take orders from the market in the context of higher education in law and administration (as well as scientific research), with artificially made demands or orders being more frequent in this area.

Another important limitation before commercialisation is that while the importance and marketability of private administration, organisation, management and related legal knowledge are unquestionable, the Hungarian public administration is satisfied in most respects with the adoption of solutions developed in other areas of social existence. If this changes on a higher system level and the public (state) administration acts directly as the customer (as has been the case with old, organisational institutes that existed before the change in regime), then we can be sure that the science of public administration will more likely appear as a popular science.

New regulatory content, legal technical novelties, new communication platforms, etc. may also generate real interest in the most diverse spheres of the general public, both in market and non-market related spheres.

Reviewing what has been said, we can see that the barriers and slowdowns in the promotion of science may be due to a lack of lasting market demand and limited domestic innovations as well as a lack of recognition that this activity can be an excellent PR tool, regardless of the direct financial return.

42 Tihamér Margitay, „Megrendelő, tulajdonos és bizalom a tudományban”, Határmunkálatok a tudományban (eds. Gábor Kutrovátz, Benedek Láng, Gábor Zemplén), L'Harmattan, Budapest 2010, 116.

${ }^{43}$ Ibid., 117. 


\section{SUMMARY}

As explained in the present study, fresh, up-to-date and interesting promotable knowledge - produced by administrative sciences - and its transfer can become important in at least three aspects: a) the knowledge accumulated in administrative jurisprudence and other fields of administrative sciences itself is new (e.g. by the emergence of administrative information technology) or a new systematisation of available knowledge can be considered a novelty; b) the target and reached audience can be considered special (e.g. children, the elderly, people in institutional care); or c) the channel and form of knowledge transfer are special. In the present study, we have sought to provide examples of all three aspects; the study covered the possibility of current/planned experiments and contemporary results becoming accessible.

While some aspects of this broad conceptualization can be contested, science promotion - in general and especially within the certain field - is an issue of growing importance also because of the third-generation universities, which, in contrast to first- and second-generation universities, actively seek the possibility of commercial utilization of the knowledge created by them. Accordingly, this science promotion serves also as an expansion tool and also as a new platform of communication.

Moreover, this phenomenon must be also taken into account as an element that makes changes not only by deepening the relations of science and its societal environment, but also within the particular field of science, leading to an intensification and transformation of inner processes.

\section{REFERENCES}

Bárdi Nándor, „Álságos állítások a magyar etnopolitikában. A külhoni magyarok és a budapesti kormányzatok magyarságpolitikája", Hegymenet. Társadalmi és politikai kihívások Magyarországon (eds. Jakab András, Urbán László), Osiris, Budapest 2017, 130-155.

Bencsik András, Fábián Adrián, Pál Emese, Szőke László Gergely, „A közigazgatás és a média kapcsolódási pontjai”, Pro Publico Bono - Magyar Közigazgatás, 4/2015, 60-75.

Bereczkei Tamás, „A manipuláció művészete. A machiavellizmus kognitív és evolúciós alapjai", Magyar Pszichológiai Szemle, 2015, 70 (1), 7-22.

Bordás Mária, „Gondolatok a közigazgatás-tudományról”, Polgári Szemle, 3-6/2012, 11-31.

Czékmann Zsolt, Kiss Lilla Nóra, „The Concept of E-administration in the Hungarian Regulation", Juridical Current, 1/2015, 73-88.

Csáki-Hatalovics Gyula, „Új trendek Európában az elektronikus közigazgatás területén", Glossa Iuridica, 3-4/2017, 70-82. 
Csimáné Pozsegovics Beáta, Sáriné Csajka Edina, „Élménypedagógia a minőségi időskorért", Képzés és Gyakorlat, 4/2017, 69-82.

Deés Szilvia, Egyetemi tudománymarketing. A harmadik generációs egyetem szemlélete és kommunikációja. Phd thesis, PTE DI, Pécs 2011, 35-36.

Fekete Mária, Grád András Pszichológia és pszichopatológia jogászoknak, HVG-ORAC, Budapest 2012.

Fleck Zoltán, „A jogászképzés módszertani dilemmái”, Neveléstudomány, 4/2018, 30-38.

Füzér Gábor, „A konzultáns, az előadó és a kapcsolatteremtő”, Üzlet és Pszichológia, 3/2013, 30-32.

Gábri Angéla, „Közérthetőség a hazai büntetőeljárási jogban”, Jogtudományi Közlöny, 12/2019, 503-511.

Gajzágó Éva, „Tudománynépszerüsítés süvöltő lángcsóvával”, Élet és Tudomány, 3/2015, 1371-1380.

Gregory, Jarrett J. et al., „Communications”, Public Administration Review, 6/1984, $551-557$.

H. Szilágyi István, „Jog és irodalom”, Iustum Aequum Salutare, 1/2010, 5-27.

Jakab András, Menyhárd Attila, „A magyar jogtudomány helyzete és kilátásai”, $A$ jog tudománya: Tudománytörténeti és tudományelméleti irások, gyakorlati tanácsokkal (eds. Jakab András, Menyhárd Attila), HVG-ORAC, Budapest 2015, 25-47.

Kissné Pap Margit, „Áttekintés a hungarológia jelenlegi helyzetéről és a fontosabb további feladatokról", Hungarológia, 1-2/2000, 25-38.

Köbel Szilvia, Az emberi jogok védelmezöiböl a ,nép ellenségei”. A Magyar Közigazgatási Bíróság megszüntetése 1949-ben. Patrocinium, Budapest 2019.

Lendvai Róbert, „Elektronikus közigazgatás kistelepülési szinten”, Comitatus, 4/2017, $52-58$.

Lévy, Bernard-Henri, „Google, fake news és az igazság válsága”, Heti Világgazdaság, $8 / 2019,65$.

Margitay Tihamér, „Megrendelö, tulajdonos és bizalom a tudományban”, Határmunkálatok a tudományban (eds. Gábor Kutrovátz, Benedek Láng, Gábor Zemplén), L'Harmattan, Budapest 2010, 116-123.

Navracsics Tibor, „Nemzeti érdek és Európa”, Pro Publico Bono - Magyar Közigazgatás, 4/2014, 100-104.

Nemes László, „Filozófiatörténet kezdőknek”, Kultúra \& Kritika: A PPKE BTK Esztétika Tanszékének kritikai portálja, 12 July 2016, http://kuk.btk.ppke.hu/hu, 13 January 2019.

Parkinson, C. Northcote, Parkinson törvénye vagy az Érvényesülés Iskolája, Minerva, Budapest 1990.

Rixer Ádám, A magyar közigazgatási jogtudomány értékelésének szempontjai [Aspects of the Evaluation of Hungarian Administrative Jurisprudence], Ludovika, Budapest 2020.

Rixer Ádám, „,Közigazgatás és szépirodalom”, Pro Publico Bono - Magyar Közigazgatás, 3/2015, 49-72.

Schöpflin György, Az identitás dilemmái. Kultúra, állam, globalizáció, Attraktor, Máriabesnyö-Gödöllő 2004, 143. 
Szabó Miklós, „Szó szerint... A jog és nyelv interferenciájáról”, Jog és nyelv (eds. Miklós Szabó, Csaba Varga), PPKE, Budapest 2000, 1-14.

Szényei András Gábor et al., „A kiégési szindróma megelőzése - a hagyományoktól a modern információs technológiákig”, Magyar Pszichológiai Szemle, 4/2015, 847-862.

Tóth Károly, „Tudomány-népszerüsítés vagy ismeretközlés?”, Korunk, 1/1974, 142-144.

Vajda Róza, „Mi fán terem az akcionista tudomány?”, Szociológiai Szemle, 1/2019, 149-161.

Z. Karvalics László, „A tudománymüvelés és a tudományokban való jártasság, mint emberi jog. Egy arkhimédészi pont azonosítása", Acta Humana, 3/2019, 119-135.

Z. Karvalics László, „Állampolgári tudomány és önkéntes erőforrásszerzés mint paradigmatikus, szakpolitikai és menedzsment-kihívás", Új Magyar Közigazgatás, 1/2019, 44-53. 
Аgам А. Риксер

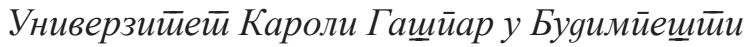

Правни факулиетеи

rixer.adam@kre.hu

\section{Наука управног права и наука о управи као популарне науке у Мађарској}

Сажетиак: Защӣоо и наука о јавној уйрави не би била јеgна о йойуларних

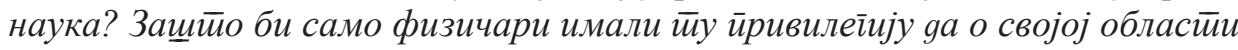
іоворе на начин који је за мнойе достиуйан, разумљив и иниеересанйан. Након

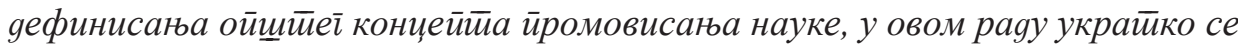
излажу основни ичиљеви иромоције, укључујући вещииине које кроз иромовисаюе највище моіу gа се развију, уйравне областии које су, йо нашем мищлеюуу, оg највећеі јавноі иниеереса, моїућностии и канали за нову комуникацију и

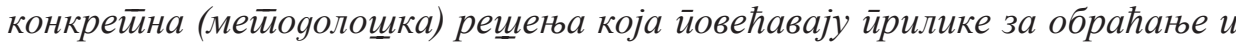

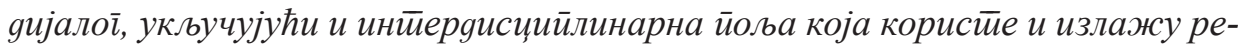
зулйайе уйравноі йрава. У настиавку, размайрају се ояі̄овори на йийаюа у вези са вешитинама и знањем које би јеgан добар ирромотерр йребало gа има

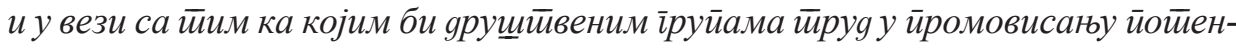
иијално моїао gа буде усмерен. У раяу се тиакође уочавају и іранице у иромо-

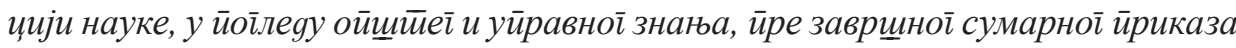
gобијених резулитайа.

Кључне речи: уйравне науке, јурисируденција, йойуларизачија, йромочија науке, Мађарска.

Датум пријема рада: 04.04.2021.

Датум достављања коначне верзије рада: 26.05.2021.

Датум прихватања рада: 08.06.2021. 